\title{
Tradition and Modernization. Contemporary Hungarian Popular Cinema*
}

The post-socialist transformation of the Eastern European cinemas is usually described from the point of view of the industrial and financial changes and the continuation of authorial filmmaking. Relatively little has been said about the position of popular cinema both during and after socialism. This situation seems to have changed over the past ten years due to the growing number of publications dealing with Eastern European popular cinema. The necessity of break with an elitist and politicized approach to the Eastern European cinemas is underlined in many scholarly publications. Anikó Imre highlighted the importance of the rediscovery of the seemingly lost but rather forgotten traditions and aspects of Eastern European cinemas:

Now we can and should refocus on the neglected production and consumption of popular films all through the socialist period: films that appropriated Hollywood generic formulas with local inflections; and that catered to desires much less easily contained by Soviet regimes than high-cultural dissidence. Many communist comedies, musicals and melodramas never crossed borders; they were certainly not exported to the West. They were enjoyed primarily by national audiences-and enjoyed a great deal, much more than high cultural opuses. But many, such as East German Westerns or children's television programmes, were produced in regional or European collaboration and distributed and viewed in most Soviet satellite countries.[1]

In her introduction to the first issue of the new journal Studies of Eastern European Cinema Ewa Mazierska discussed why popular cinemas could be significant in the context of the post-socialist or post-communist transition:

While the collapse of communism was not a necessary condition to discover the popular aspect of communist cinema, it certainly facilitated it. The reason was that first, before 1989, popular cinema was treated with contempt, either as an opium for the masses, manufactured by second-rate film-makers obedient to the regime or as an inferior type of resistance towards the communist rule. Second, the fall of communism created specific conditions that allowed a nostalgic detachment from the past. Although this yearning for the communist past, explored most famously in the book by Charity Scribner (2003), faded with the passage of time and nowadays

* This essay was supported by the János Bolyai Research Scholarship of the Hungarian Academy of Sciences.

[1] I. Anikó, "Dinosaurs, Moles and Cowboys: Late
Images

vol. XIII/no. 22

Poznań 2013

ISSN 1731-450x 
the vast majority of citizens of Eastern Europe are glad that communism collapsed, it put its distinctive mark on the way the communist period is perceived. Third, the fact that box office success matters so much in contemporary cinema invites a comparison of the old and new films from the same perspective. I predict that the more time that passes, the more respected popular Eastern European cinema will become as an object of academic study.[2]

The integration of Eastern European screen industries into the global entertainment industry evidently highlights the situation and status of popular cinemas in the region, and is one of the most obvious reasons for examining these films in transnational context. However, "national" framing seems to have some remaining importance due to the fact that local/national cultural traditions has always been determinant factors of popular cinema and, in contrast to auteur cinema (and of course Hollywood productions), rarely travel well beyond domestic markets.[3] Thus, the interplay between global (or, rather Hollywood-like) popular genre patterns and local or regional contexts and traditions is one of the most prominent questions and aspects of (Eastern) European popular cinemas. This article provides an overview of recent trends and problems in Hungarian popular cinema with special regard to its cultural context, outlining the process of recognition of popular cinema over the past twenty years in Hungary.[4]

In brief, the most important characteristics of Hungarian popular cinema are: (1) the discontinuity of its tradition (ruptures and resumptions over and over again); (2) the decisive role of local popular culture in the formation of Hungarian popular cinema; (3) the relatively narrow scope of genres in Hungarian popular cinema. In general, Hungarian cinema is characterised by middle-range genres (dominantly comedy) and not by a broad scope. Thrillers, horrors or sci-fis are rare birds in Hungarian cinema (even if we compare it

[2] E. Mazierska, "Eastern European Cinema: old and new approaches," Studies in Eastern European Cinema 2010, no. 1, p. 12.

[3] The rare Hungarian popular films (comedies like A Kind of America and Out of Order) which were distributed abroad usually had 10,00o admissions at the maximum. The only exception I know is Control, Nimród Antal's thriller which had approximately 150 , 000 admissions in Europe (half of them in Poland). Auteur films travel more and perform better: Béla Tarr's Turin Horse had 50,000 admissions in Europe, György Pálfi's Hukkle and Taxidermia had 30,000 - they doubled or sometimes multiplied their domestic admissions. From the middle-brow sector: Lajos Koltai's Fateless (2005) an adaptation of Imre Kertész's Nobel prize-winning novel, was widely distributed in Europe and had 100,000 admissions, and István Szabós international co-production family saga Sunshine (2000) had 300,000 admissions in Europe plus 900,000 in the US. (Source: Lumiere Database, European Audiovisual Observatory) [4] I will use the term "popular," referring the popularity of the films in question in this text, which concentrates on local box office hits in Hungary. I will not use the term "mainstream cinema," which is broader than "popular cinema" and will not discuss the question of Hungarian middle-brow cinema, although the hybridity (popular \& auteur) of István Szabó, Pál Sándor, György Szomjas, Péter Gárdos and Géza Bereményi's films (to name but a few) might be interpreted from this perspective, as well. However, I will refer to genre films and genre-based filmmaking, which is not an ovelapping category with popular cinema. A genre film is not necessary popular, and a popular film is not necessary genre-based - specially in Hungarian or Eastern European cinema. 
with other Eastern European cinemas).[5] Almost every decade in the classical and modern Hungarian film history might be described by its dominant genre: in the 1930s it was comedy, in the 1940s melodrama, in the 1950 s comedy and operetta, in the 1960 s historical film adaptations, in the 1970s comedy, in the 1980 comedy and animation, and in the 1990 and 2000 s comedy again. Not much variety. Supposedly it is exactly the discontinuous tradition and narrow genre spectrum that account for the self-containment of Hungarian popular cinema; however, the fact that it is traditionally almost solely confined to comedies does not mean that there have been no experiments with other genres or efforts to adapt foreign models. The history of genre experiments in Hungarian cinema is an exciting subject, as almost all the genres not mentioned above, though generally lacking in Hungarian popular cinema are not completely absent. There are Hungarian thrillers, horrors, action films and sci-fis; there is also a Hungarian version of the Steven Segal-like action film (Europe Express, 1998) or the Guy Ritchie-like gangster comedy (Argo, 2004), but these films were not successful or stand alone because they could not start a cycle of films using similar motifs, patterns and heroes.[6] Fallen attempts and unprecedented films are also of importance, but this article will focus on the recurring motifs and predominant genres in Hungarian popular cinema.

The transformation of the Hungarian film industry during the late 1980 os and early 1990 s was relatively smooth, compared with othOnly tradition er Hungarian cultural sectors and with other Eastern European film industries. The system of state-owned studios and the socialist model of financing broke up during the years of the transition; however, the establishment of a new and self-governing public body, the Motion Picture Foundation of Hungary, as early as 1991 provided the film industry with a new institutional framework. For twenty years, this Foundation was the central institution in the Hungarian film industry, responsible

[5] On Eastern European comedies: C. Eidsvik, "Mock Realism: The Comedy of Futility in Eastern Europe," [in:] Comedy/Cinema/Theory, ed. A. Horton, University of California Press, Berkeley 1991, pp. 91-109. Christina Stojanova in her overview focuses on three genres: melodrama, "mafiosi-thriller" and historical epics. C. Stojanova, "Post-Communist Cinema. The politics of gender and genre," [in:] Traditions in World Cinema, eds. L. Badley, R.B. Palmer and S.J. Schneider, Edinburgh University Press, Edinburgh 2006, pp. 95-114. On generic revisions of Eastern European cinemas: A Companion to Eastern European Cinemas, ed. A. Imre, Wiley-Blackwell, London 2013. On some Hungarian (and Eastern European) "Eastern Western" and their cultural context see: A. Imre, "Eastern Westerns: Eenlightened edutainment and national transvestism," New Review of Film and Television Studies 2011, no. 2, pp. 152-169. [6] It worth noting that sometimes even the most popular directors' genre-changing experiments have been unsuccessful. Gábor Herendi after the tremendous success of his romantic comedy ( $A$ Kind of America, 2002) and historical comedy (Hungarian Vagabond, 2004) made an excellent melodrama (Lora, 2006) which had a far lower attendance than his comedies. Similarly Krisztina Goda's thriller, Chameleon (2008) could not reach the success of her romantic comedy (Just Sex and Nothing Else, 2004) or historical drama (Children of Glory, 2006). Comedy wins it all in the Hungarian cinema market. 
for the distribution of annual state support for the industry.[7] Although this annual support was worth less and less during consecutive years due to inflation, Hungarian filmmakers could take satisfaction in their successfully breaking with political control and censorship and setting up a new system which safeguarded some degree of state support. But in terms of distribution and exhibition, the Hungarian film industry's transformation was as tough and rapid as everywhere else in the former Eastern Bloc. After the state's monopoly on distribution was ended, cinemas were flooded with American films. Almost everybody felt that local films could not compete with American blockbusters, which is likely one reason why there were no serious attempts to revive Hungarian popular cinema. Filmmakers were not encouraged to make business or entertainment, but they also had no experience at it, either. Furthermore it was not clear which was more risky: making an auteur film using previously tested methods, or making a popular/genre film? Those filmmakers who liked challenges and wanted to test themselves chose business: they set up small companies and made commercials instead of "commercial" cinema. Thus, the transition of the industry resulted in the survival of auteur cinema, which preserved a kind of financial maintenance but lost its political significance - and almost completely lost its domestic audience. Cinema attendances dropped abruptly overall during the first half of the 1990s, but the market share of Hungarian films dropped even more: to between one and five per cent. Among the rare popular films, we can find absurd comedies depicting everyday life in postcommunist Hungary (Péter Tímár's Slap Jack from 1991 and György Szomjas's Junk Movie from 1992; both directors had earlier experience with hybrid popular-auteur films), but the overall situation was depressing.

It was not a question of whether there was a demand for popular films in Hungary, but rather what they should be like. The pre-WWII film industry seemed to provide the best available clues, and so it was this tradition that filmmakers tried to revive. In the second half of the 1990s, the pre-war, theatre-based comic tradition, full of witty dialogues and cabaret-like situations, featuring the greatest actors, was continued in We Never Die, Stracciatella and Out of Order. Audiences were hungry for familiar faces, so it was no accident that most of these films were directed by successful actors.

The unexpected success of actor-director Róbert Koltai's bitter-sweet debut comedy, We Never Die in 1993 served as a paradigmatic new-and-old model for a popular Hungarian film. The story features the adventures of a small-time salesman who is obsessed with woman and horse races, and who tries to survive in the post-totalitarian early 1960 s in Hungary. The survival strategy of a clumsy but lovable hero, a Svejkian character familiar from Eastern European film history, and specially from Czech comedies and new wave films, provided a senti-

[7] On the transformation of the Hungarian screen industries see Balázs Varga: “Take the Money and...?
Questions of Self-governance in the Hungarian Film Industry," Iluminace 2012, no. 4. 
mental and nostalgic, albeit somewhat ironic view of the Kádár-regime. We Never Die received fastidious reviews, and only after its resounding success did "revised" appreciative criticism start to appear on the film.[8]

In 1990 s Eastern European cinema, we can see that unexpectedly successful films were often emblematic and could play a decisive role in shaping the trends of a given country's cinema. Jan Sverak's Kolya represented the continuity of the tradition of Czech comedies and new wave cinema; Władysław Pasikowski’s Psy transfered (and transformed) Bogusław Linda's persona and character from auteur cinema into action-oriented popular culture, and represented Polish cinema's openness to trends from contemporary genre-filmmaking. And Róbert Koltai's We Never Die signalled Hungarian cinema's turn back to the tradition of 1930 comedies.

In the wake of We Never Die, several film were made which utilized this formula (Róbert Koltai: Samba, Professor Albeit, András Kern: Stracciatella). Sitcoms with lovable, clumsy heroes who are lost in the everyday, but through luck always find their way out of the glorious mess they have made. These films were typically made by actor-filmmakers and started a new era of local stars (was the case in the 1930 and 1940s). The most notable of this series is Out of Order (1997), which was produced by Andy Vajna and became the most successful Hungarian film in the past 25 years, with more than 600,000 admissions. [9] The Hollywood producer Andy Vajna, who in 1989 founded the Hungarian market-leading distribution company InterCom, wanted to show it was possible to make a Hungarian film that would attract hundreds of thousands of viewers. Out of Order is based a comedy by Ray Cooney which was a theatrical success at that time in Budapest, with Róbert Koltai and András Kern in the leading roles. The film adaptation of the comedy was supported with a never-before-seen publicity campaign and became a box office hit. This recipe of Hungarianized slapstick comedies and/or sitcoms was successful even in the 200os, although in an upgraded and refreshed version. The popular actor Péter Rudolf's Glass Tiger (2000) later became a cult hit and had two sequels. The heroes of this comedy are a bunch of friends who want to run a small kiosk in a trailer along a road somewhere in the countryside. The crazy, comic, and miserable characters, their pathetic adventures and friendship, and their gags and jokes are somehow emblematic of how Hungarian popular culture imagines typical local and loveable heroes. The Glass Tiger series, which lies somewhere between the emphatic humour of Czech comedies and the Kusturica-like Balkan farce, perfectly represent contemporary Hungarian popular cinema's in-between-ness.

[8] The leading Hungarian cinema monthly magazine Filmvilág, published only a short and not-so-warm review (G. Schubert, "Sose halunk meg," Filmvilág 1993, no. 3, p. 57), but eight months later in a leading article, they discussed the "secret of the success" of the film (T. Hirsch, "Csak kétszer élünk," Filmvilág
1994, no. 2. pp. 17-20). Furthermore, the Hungarian Film Critic's Association gave a special prize to We Never Die for "winning back" Hungarian audiences in 1994.

[9] This is the only Hungarian (and non-Hollywood) film that made the attendance top-list for 1990-2012. 
In 1997, besides Out of Order, another Hungarian film was a surprise hit. Péter Tímár's musical comedy Dollybirds likewise did not give an uncritical, sentimental account of the atmosphere of the past era. The film lived up to expectations: reviving the past and keeping an ironic distance at the same time.[10] The story took place in the early 1960 , and followed the struggles of a young amateur rock band which wanted to get to the "promised land," Helsinki, by winning a local talent show that had mobilized the whole population. By conjuring up 1960 s fashion and displaying period-like objects (bulky radios, tape recorders, refreshments), the film did not aim to give a realistic or nostalgic picture of the period, but rather to recreate its atmosphere. The film's distance and reflection are enhanced by music-video-like elements (fast forward motion, the asynchronization and manipulation of motion and dialogues), which dictate the film's energetic pace. Its use of music exemplifies this intention perfectly: parts of banal, mellow period hits were re-orchestrated without any major changes, while others were completely rewritten and presented with great humour and irony in a deformed version.[11]

Dollybirds, providing a perfect and inseparable mixture of ironic nostalgia and nostalgic irony, won a shared first prize at the Hungarian Film Festival. Reviews were quite positive, proving that success does not necessarily go hand in hand with the scorn of critics. However, Tímár's next films did not continue this ironically nostalgic postmodern retro-fashion, but rather take the way of old-fashioned slapstick comedies (Feri's Gang, Heads Off), somehow confirming the strength of this tradition in Hungarian popular cinema.

This tradition of comedies continued until the end of the millennium with remakes of classic comedies (Hyppolit, Dream Car, One Fool Makes Many, One Skirt and a Pair of Trousers). The first film in this list was Barna Kabay and Katalin Petényi's new version of a legendary film from the 1930s, one of the first Hungarian talkies. The original, Hyppolit, the Butler is a witty caricature of the era's bourgeois gentilhomme, and its protagonist, Gyula Kabos was a legendary figure in Hungarian popular cinema. Kabay and Petényi modernized the story using the similarities between the two eras. The parvenu entrepreneur, who is loaded with money, but lacks good manners, and tries to assimilate to the values of high society provides a good topic for a great satire. Unfortunately, the film and the subsequent remakes as well, merely scratched the surface of these strange social relations, and, apart from one or two great actors, they showed little originality. These films were popular, but their histrionic style was out-dated. Adapting successful classical comedies

[10] On the representation of the 1960 and on the questions of ironic nostalgia in Dollybirds, see F. Krisztina, "Innocence Lost. Cinematic Representations of 196os Consumption for 1990s Hungary," Anthropology of East Europe Review 2006, no. 2, pp. 54-61.
[11] The use of the musical form to create distance from a nostalgic representation of the past took place in different ways, but include the Hungarian Dollybirds, Made in Hungaria (Gergely Fonyó, 2009) the Czech Rebelové (Filip Renc, 2001), and the Russian Stilyagi (Valery Todorovsky, 2008). 
made in the 1930s offered only a temporary way out, and the cycle of remakes winded down at the start of the new millennium.

Historical epics/literary adaptations played an important role in 1960 s and somewhat in 1970 s Polish and Hungarian cinema. This is a tradition which was clearly continued in contemporary Polish cinema, but seems to be ambiguous in Hungarian cinema. The contemporary run up of Hungarian historical cinema coincided with the celebration of the millennium of the Hungarian state. During that time, several historical films dealt with topics from past centuries. One of the most excellent Hungarian animation directors, Marcell Jankovics, revived the world of legend and the story of Hungarians' origins (Song of the Miraculous Hind). Gábor Koltay's Sacred Crown is a medieval historical epic. Csaba Káel made an adaptation of one of the most important Hungarian romantic operas (Bánk Bán). However, it was Géza Bereményi's Bridgeman that was given the most exposure. This was the most expensive Hungarian film of all time, the greater part of the 11 million euro budget having been subsidized by the cultural ministry. Preparing, shooting and budgeting the film created a political debate and divided public opinion sharply, especially since at that time the film industry was struggling with impossible financial conditions. The film adapted the life of one of the most outstanding statesmen of the Hungarian reform age in the 19th century, István Széchenyi: featuring extravagant photography, the film made a driven and sensitive man's drama its main theme.

Polish historical films are usually interpreted from within the frame of heritage cinema, although scholars have drawn attention to the fact that the label "heritage" does not exist in Polish cinematic terminology - sometimes such films are described as the "cinema of school canon," "superproductions" or simply as "literary adaptations." [12] Hungarian historical films (The Conquest; Sacred Crown; Bridgeman; Bánk Bán) from around the millennium are rarely discussed in this context. This is understandably because they differ not only from mainstream European and English heritage films, but from their Polish and Russian counterparts. Notwithstanding, a quick comparison is worthwhile, especially since the term "heritage cinema" could provide a useful frame for understanding national cinema cultures in a larger (international, global) context. As Belén Vidal has put it:

The heritage film thus has become a supple term to refer to the ways in which national cinemas turn to the past at different moments in their histories in search of their own foundational myths. At the same time the genre also highlights the strategic positioning of national film industries in the global markets and their need for expansion through transnational alliances.[13]

\author{
Historical epics, \\ or Hungarian heritage \\ cinema?
}


While these Polish films are usually discussed in the context of each other and promoted as belonging to the same genre, the context of the Hungarian historical/heritage film is a primarily political.[14] In opposition to the prominence of literary adaptations in Poland, there are no direct literary inspirations behind such Hungarian films (except Bánk Bán). Thus, Polish heritage films represent a continuity in the tradition (even given the fact that Jerzy Hoffman himself made the most representative heritage films both in the 1960s-70s and the 2000s). But their patriotic and patriarchal Hungarian counterparts are only indirectly connected to the tradition of Hungarian historical epic/literary adaptations from the 1960s. Both Polish and Hungarian films share a pedagogical aspect of cinema; however, the Polish films were produced to be distributed beyond the local market, while the Hungarian Bridgeman or Sacred Crown focused rather on the domestic market.[15]

\section{The modernization of Hungarian popular cinema and the transformation of the film industry}

While at the beginning of the 20oos, it seemed that the audiences were slowly finding their way back to local films, the dynamics and overall trends in Hungarian popular cinema were becoming more and more outdated. Hungarian cinema needed young filmmakers with a fresh perspective, who knew genre patterns and contemporary trends, who were not burdened with the attitudes that prevailed during the socialist era, and not captivated by the singular tradition of Hungarian comedy. One of the most important prerequisites for making a popular film or a successful genre film is both the filmmakers and the audience being aware of popular myths and genre rules. In Hungary and during socialism, however, the patterns of popular film culture had been somewhat unknown to directors and viewers alike for quite some time. The most important Western (Hollywood) films rarely reached the Eastern Bloc or at least did so with much delay. This was not the case in the late 1980s, but it seems that at that time Hungarian popular cinema looked for the future in its past (the theatre-based comedy tradition of the 1930s) and not in contemporary global trends. The new generation of the $2000 \mathrm{~s}$ luckily did not worry about elitist concerns nor try to revive successful but outdated patterns, and wanted instead to make genre films based on contemporary trends transferable to Hungarian local culture.

The first sign of this change in trends was Gábor Herendi's A Kind of America (2002), a romantic comedy about three brothers
[14] "Viktor Orbán’s Fidesz government was encouraging and financially supporting a number of films which suited its political stance and programme. All these films have treated historical topics with a decidedly patriotic slant which, it is alleged, Fidesz has tried to link with its own political posture." J. Cunningham, Hungarian Cinema: From Coffee House to Multiplex, Wallflower Press, New York 2004, pp. 156-157.
[15] Gábor Herendi’s Hungarian Vagabond (2004) one of the most popular films of the decade is in a way an ironical interpretation of Hungarian historical epics. Its heroes, the leaders of the Hungarian tribes, wake up on the day after a big party to realise that their subjects have started the Magyar Conquest without them. So they set out to find the Hungarians, and their wanderings up to the present day become a crooked reflection on Hungarian history over the past centuries. 
and their love affairs. Herendi's film was a surprise hit with more than half a million viewers. The almost unprecedented success of $A$ Kind of America somehow set new directions in Hungarian popular cinema: instead of the patterns found in classical Hungarian comedies, the international comedy of the 2ooos, namely the romantic comedy, had arrived in Hungary. The top-list of the decade is dominated by this subgenre. Besides Gábor Herendi's A Kind of America and its sequel from 2008, there was Krisztina Goda's prominent Just Sex and Nothing Else (2005), which was labelled "the Hungarian version of Bridget Jones" although there are significant differences between the two films in tone, atmosphere and dramaturgy. Goda's next film Children of Glory (2006), produced by Andy Vajna, was a Hollywood-style romantic drama set during the events of the 1956 Hungarian revolution. In its kind, this was the one of the first notable attempts to reshape a local (regional) genre-version, the historical drama, which over the past decades had been associated with auteur cinema and political commitment.

One of the most notable non-comedy examples of genre experiments is the debut feature film Control (2003) by Nimród Antal. The heroes of this thriller, coloured by dark, grotesque humour, are extravagant ticket inspectors in the metro, and the story focuses on the strange identity-quest of the head of an inspector team, Bulcsú, who is completely withdrawn from the world above, living under ground day and night. Control was the surprise hit of that year, acclaimed by audiences, critics and the international festival-circuit. Antal was born in Los Angeles, but studied at the Hungarian Film Academy. After his Hungarian debut, he returned to Los Angeles and continued his career in Hollywood (Vacancy, 2007, Armored, 2009, Predators, 2010, Metallica: Through the Never, 2013).

Top-list is a keyword for the 2000 s in Hungarian cinema. The importance of attendance figures was evident for everybody, and special efforts were made to support Hungarian films which might be successful at the cinemas. In 2003, the Motion Picture Foundation of Hungary had an unique tender: they gave extra support to "expected successful films." This grant were given to productions who "promised" to have 80,000 or 100,000 viewers. If they could not reach these figures, they had to pay back the money. This tender signals that from the early 2000 on, commercial success as a kind of legitimation of domestic cinema has become more and more relevant.

The 2000 s brought not only the modernization of Hungarian popular cinema, but parallel to this, a reshaping of the Hungarian film industry. The main components of the turn in trends were partly institutional and cultural. Institutionally, the turning points were the start of Hungarian commercial television, the opening of multiplex cinemas (these events happened independently but in parallel in 1997) and changes in legislation (i.e. the "Hungarian film law" passed in 2004). The start of Hungarian commercial television radically reshaped both the domestic television market and local popular culture. Reality shows, 
quality TV series and programs (and its local versions) appeared, and, more prominently, a new local celebrity culture was born. Likewise, the opening of multiplex cinemas altered the local market, setting up new and higher standards of exhibition. Low-budget Hungarian films, often of poor technical quality (shot on DV, recorded using poor or outdated sound technology) and lacking sufficient prints for saturated distribution, completely lost their chance to achieve a broader audience through multiplex screening. In sum: the start of Hungarian commercial television and the opening of multiplex cinemas substantially transformed the Hungarian screen industry and mediascape, as well as the production, distribution and reception of local popular culture. The new "standards" were not only technical. New and globalized narratives, forms and content dominated the screens. At the end of the 1980s, Eastern Europe's screen industries had come to an end. At the end of the 1990s, the Hungarian screen industry had definitively entered the globalized audiovisual market. A third important factor in the modernization of Hungarian popular cinema, the Hungarian film law of 2004, reshaped the institutional and legislative context of Hungarian screen industry.[16] The aim of the Law was to strengthen the competitiveness of the Hungarian film industry by offering it tax incentives and supporting Hungarian cinema culture.

On the one hand, the Law created the legislative and financial conditions for revitalizing the Hungarian film industry. This was all the more needed because during the 1990s Hungarian studios and infrastructure had become run-down and the Hungarian film industry had lost its competitiveness, even on the Eastern European market. With a generous 20 percent tax incentive (i.e. films for cinema and television produced in Hungary were and are still eligible for a 20 percent rebate based on their expenditure emerged in the country), Hungary gained a strong position in the global "subsidy race" for American runaway productions. But incentives are only one side of the market supply: there must also be a technical infrastructure, expert local crews, and huge studio complexes for filming big budget international productions. Between 2004-2006, a number of private film studios were built in Hungary (Korda Studios in Etyek, Raleigh Studios in Budapest and Stern Studio in Pomáz - all the three studios in Budapest or near to the capitol), which used the most updated technology and were capable of serving even A-category Hollywood productions. Thus, with the help of tax incentives and the availability of private studio facilities, the Law helped to transform and modernize Hungarian film industry.

On the other hand, the Law reinforced the position of the Motion Picture Public Foundation of Hungary as the industry's main public body. Annual state support was increased. The working and the support system of the Foundation was reformed, and new types of support were

[16] http://magyar.film.hu/fih/news/what-is-the-mo-

tion-picture-act-about-hungarian-motion-picture-

-act.html (accessed: October 14, 2013). 
implemented. From the perspective of Hungarian popular cinema, the favourable changes included so-called "normative grants," which were given to productions that had high domestic admission figures. [17] The fact that "normative grants" were given by admission and by festival prizes showed that important changes were taking place in the policy behind public support: the parallel structure of these "normative grants" valorised both artistic and popular success (festival prizes and cinema admissions).

Another significant change was that the structure of the Advisory Boards of the Foundation changed. While during the 1990s, there was only one Board which evaluated applications, from 2004 on, the number of boards multiplied. There were special boards for co-productions and television series, and there were years when productions could apply with their project to a special board for popular films, as well. In order to get back audiences for domestic productions, distribution companies got special support for promotion, and at least two prints were released of every Hungarian film (so as to be "visible" on the art cinema circuit).

Besides the changes in the support system, the growing recognition and importance of popular cinema was reflected in the reception and even in the canonization of Hungarian films. The 2000 s was not only a decade that saw a new and young generation of film-makers, but a time when a new generation of critics came onto the scene, as well. These young critics knew film history as well as contemporary popular cinema, were familiar with genre patterns and American-style scriptwriting manuals, and had no prejudice against popular cinema. Careful critical reception and analysis of the know-how of Hungarian popular cinema had an important role as a mediator between the industry and the audience. There was another aspect in this canonization: in 2007 the main prize was doubled at the Hungarian Film Festival. Besides the best auteur (art) film, the best popular (genre) film was awarded with the main prize.

The changes in the support system (a special tender for "expected successful films"; "normative grants" given on the basis of attendance), canonization (main prize for the best popular film) and reception reveal special aspects in the process of recognition of popular cinema in the 2000 in Hungary.

The prosperity of the 2000 in Hungarian cinema, after all, concluded in a crisis. State support did not increase, and there were serious cuts in the annual budget of the Motion Picture Public Foundation of Hungary. However the Foundation supported more and more films and this over-supply was secured by bank loans, which led to a debt-trap and the Foundation's financial crisis. After the 2010 election, political support was lost, as well, and the new government shot down the Foundation due to its financial mismanagement. In place of its previous

[17] The amounts of these "normative grants" differed in every year, but were roughly between 50 million and 100 million HUF. 
self-governing structure, a new system was set up, and Andy Vajna was appointed government commissioner for the renewal of the industry. The Foundation was replaced by the Hungarian National Film Fund, which is backed by revenues from the National Lottery (and not from the annual state budget). The Film Fund's budget for 2013 is 17 million euro, which is higher than the funds the Hungarian Motion Picture Public Foundation ever had to offer for feature film production.[18] The transition period in the support system lasted for almost two years, while Hungarian film production all but stopped. The first films supported by the Film Fund were released in Autumn of 2013.

The fact that the government appointed Vajna to supervise the industry (he is a member of the Film Fund's decision-making five-member Board) has sometimes been interpreted as a radical turn towards popular filmmaking. The Film Fund evidently highlights the importance of well-written scripts and focuses on project development. But regarding the distribution of support, it seems that they are trying to keep a balance between auteur films and popular cinema. The history of Hungarian auteur film has not yet ended, but the golden age of Hungarian popular cinema has not yet started, either.

Popular films and genre films are being made in Hungary in a growing number, but the overall situation is still controversial. The necessary components for a strong popular cinema and genre-based films are still unstable. Genre-based production and genre formation, on the one hand, is a question of quantity; on the other hand, it is a question of cultural practices. It is quantitative in the sense that generic production is a recycling process which connects a series of films with each other and this process requires a "critical mass" of films. It is also a question of cultural practices in the sense that it essentially needs shared and common experiences (stories, heroes, myths) and the collective elaboration of these experiences in various ways. This includes industrial practices (modes of production, distribution and promotion) and cultural practices (public discourse, reception), as well.

Genre-based popular film production needs a vital industry, popular (film) culture and the reflexive practices related to social and cultural life. These premises have not completely been worked out in contemporary Hungarian cinema, though they are not totally lacking, and in some ways, the situation is better than ten years earlier. Primarily, thanks to the film law, the legal, financial and infrastructural facilities are better. Newly built private studios are primarily serving big budget Western films and Hollywood runaway productions, not Hungarian film; notwithstanding, Hungarian cinema, and naturally, the Hungar-

[18] One of the distinctive differences between the two public institutions is that the former's support was extended to the entire industry (development, production, distribution, exhibition, features, short, non fiction, animation and even research and publications), the Film Fund only supports feature films (from development to distribution), while the other types of production support now come from the National Media and Infocommunications Authority. On the Film Fund's activities: http://filmalap.hu/en/ images/stories/overview_may2013_download.pdf (accessed: October 14, 2013). 
ian screen industry is among its beneficiaries. Secondly, over the past years popular cinema has gained recognition both in Hungarian film industry and in public discourse (in film criticism and in the curricula of film studies, as well). We cannot say that Hungarian cinema, which was once a paradise for auteur films, has been transformed into a "small world of popular films." But something has indeed changed over the past decades. The two determining traditions of Hungarian cinema (i.e. auteur films and popular films) are somehow in balance. And this may be crucial for local filmmaking regaining both prestige and popularity.
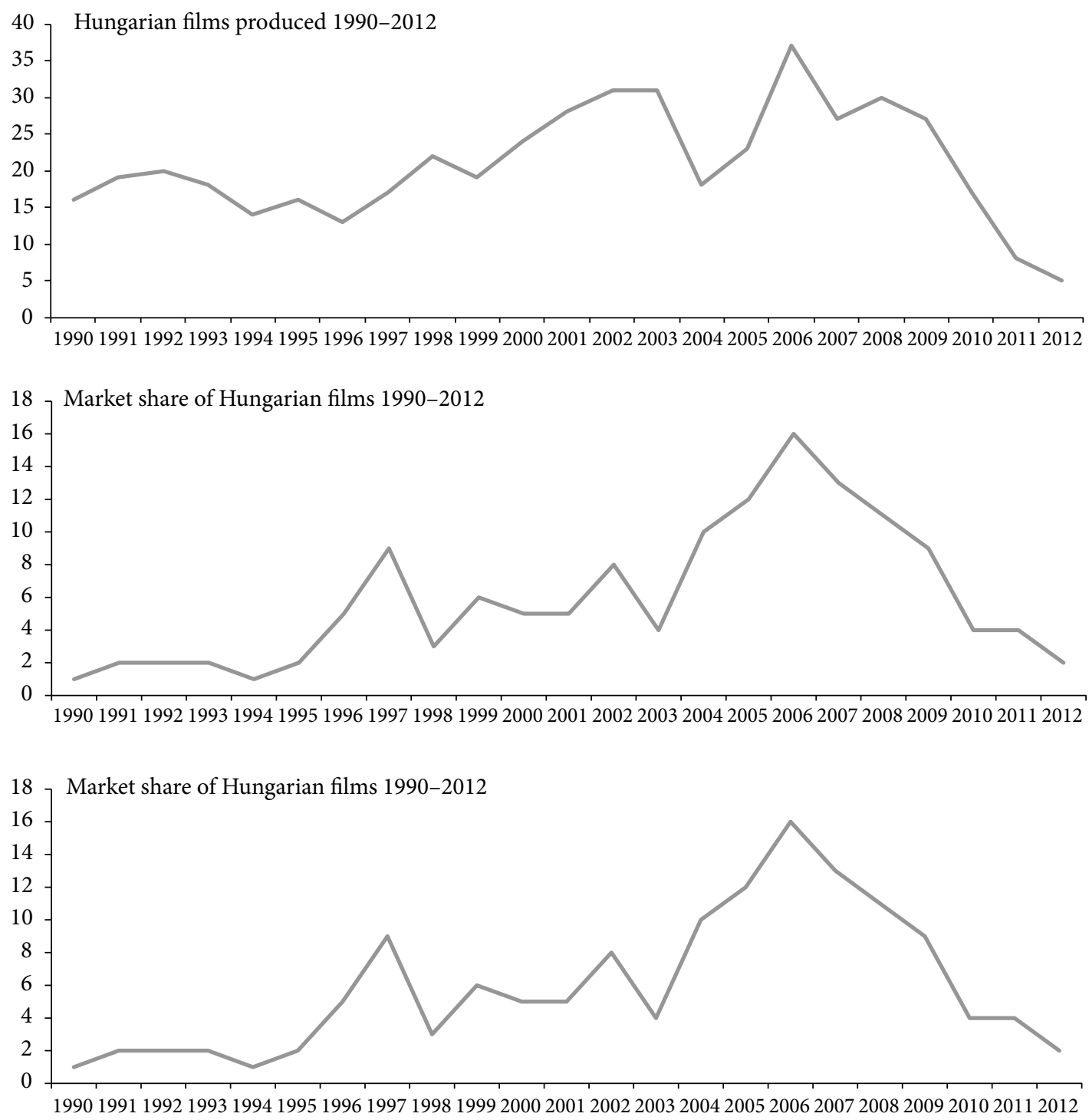

Sources: Hungarian Film Guide, Hungarian Film Yearbook, National Film Office, European Audiovisual Observatory. Due to the diversity of classifications (criterias for national productions/coproductions), different institutions and publications issues' diverse figures during my work I tried to unite various statistics. 